【Letter to the Editor】

\title{
哲学でスピリチュアルを考える \\ An Argument for Spiritual from a Philosophical Point of View
}

\section{三井 康利 ${ }^{*}$ \\ Yasutoshi MITSUI* \\ 聖隷沼津病院 \\ Seirei Numazu Hospital}

【キーワード】スピリチュアル（霊性），哲学

Key words: spiritual, philosophy

WHO（世界保健機構）は健康を, 「完全な肉体的, 精神的及び社会的福祉の状態であり, 単に疾病または病弱の存在 しないことではない」と定義している1)。これは，半世紀以上前の定義であり，個々人の意識や外部環境が変化した現 在では，普遍性を失いつつあるといえる，改正には至らなかったものの，1999 年の WHO 総会では，健康の定義に，ス ピリチュアル (霊性) を含めることが提案された ${ }^{2)}$. その後も議論は続き，Awofeso は，21 世紀の健康とは？ と問い， 生一死一生のサイクルを特徵とした，オーストラリア・アボリジ二の健康概念に触れ，WHO の健康定義を，スピリチュ アルを含めて再定義することを提案している3 . 統合医療の分野でも，スピリチュアルを含めて考える動向が見られる4).

スピリチュアルという, 心身に対して高次の感覚を希求すること. そして, 現代文化が棄却してきたものを, 原始文 化に見直す動きは，矛盾や閉塞感に陥った現代文化に対しての，反動形成や逃避，あるいは退行であると受け取ること もできる. しかし，アボリジ二の文化に見ることができるょうな, 生一死一生といらサイクルは, 過去生や死後の世界 が存在するのかもしれないといら，通文化的な直観でもある.

スピリチュアルを疾患の治療に利用する動向も見られる. その一例として, 前世療法があげられる. Weiss は, 被験 者が退行催眠中に, 生前の記憶を話しはじめ, そのことが心的外傷に対して治療効果をもたらしたことを報告してい $ろ^{5)}$. 催眠によって誘導された前世記憶の多くが空想の産物であるといら批判がある ${ }^{6}$ 一方で, 史実と照合し, 前世の記 憶そのものとしか判断できないとする報告もある7). 世迷い事から目を背けたいといら思いから，すべてが捏造された ものであると，徹底した否定の立場に立つことは簡単であり，当たり前でもある．また，たとえ効果があるからといっ て，何でもが許されるわけではない，人間には，善や美とともに真もまた大切である.

しかし，客体を一旦切り離し，主体だけを考えたとき，理論上は，輪廻は存在可能である．今回，前世を足がかりと して，哲学的手法でスピリチュアルを考察してみたい．

前世とは，自分はかつて，時間的接点のない，ある人物を生きたというふらな，過去生であるといえる，この，過去 の「私」といら存在は, 概念として, なんとなく無意識に感じることができる. この, 過去の他者と, 現在の自分を繋 ぐ媒質が，「私」でありスピリチュアルに属すると推察する.

ここで，過去生が成立するときに生ずる，大きな疑問を考えてみたい，過去生を感じるとき，いったい，自分自身の 何が，過去を生きたのかといら疑問が起こる，現在の肉体を持った，自分自身そのものではないことは明白である．肉 体は死んだらそれまでであるから，過去を生きたのは，普段感じている全くの自分そのものではない，ここから，日常 的に感じている自分と，過去生を考光るときの「私」の間に差異が生じる．この差異から，ひとつの要素を取り出すこ とができる. 全く接点をもたない別の人間に対して，肉体を含まない「私」を投射することによって，過去生が成立し ている.したがって，「私」とは，肉体を必ずしも必要としない何かである。つまり，自分を構成する要素には，肉体に とらわれない「私」が存在することがわかる.

受理日 : 2010 年 8 月 18 日

* 干410-8555 静岡県沼津市本字松下七反田 902-6 聖隷沼津病院内科Ｔel: 055-952-1000 Fax: 055-952-1001 E-mail: ymitsui@seirei-numazu.com 
一方，「私」といらスピリチュアルを，たとえば Dawkins が主張する，「肉体は遺伝子の乗り物である」 ${ }^{8)}$ とららど までに，物質的な肉体や遺伝子に投射したときには，死んだらそれきりであり，前世や来世は存在しない，遺伝子が前 世や来世だといらこともできるだろらが，継承されなければ「私」は途絶える．現代人の多くはこのような感覚を持つ のかもしれない，しかし，人間の本質が，物質のみからなるという，極端な唯物論的，実存主義的な捉方方はむしろ不 自然である，なぜなら，物質である肉体は，絶えず外部世界から物質を取り込み，外部世界に老廃物を排泄し，成長や 老化しながら変化している．非自己を取り込み，それが自己となり，また，それが外部に排出されると非自己になるの である.つまり，自己であったものが自己でなくなり，自己でなかったものが自己になるといらことが生涯にわたって 繰り返されている．肉体は，自己と非自己が交錯するダイナミック（動的）な存在であり，つかみどころがない，とこ ろが，普段我々は，時間軸に対して同一ではない，常に変化する肉体を，一生にわたって同一の自分であるとみなして いる. したがって，普段自然に感じている，このような同一性を生み出す感覚は，正確ではなく，極めて近似的な固定 観念であることがわかる，そして，「私」といらスピリチュアルが，同一といら不変であるならば，常に変化する肉体で はなく，一生という時間軸に存在していると考㝋られる。つまり，「私」は肉体が存在する空間ではなく，時間とょり強 く結びついていることがわかる。しかし，「私」が肉体とのものであると誤解し盲信するならば，死によって肉体が空間 から消滅したとき，時間は止まり「私」は終わる，これは，ディオティマのいう「人間は激しく不死なるものを恋し求 める」に表現される，強いエロス（恋）的な欲求と強く葛藤する．この葛藤を調停するために，必ず肉体を必要とする 強い自我が，永遠の「私」を望むとき，過去の他者の肉体を借りて，心理の働きによって過去生を作り上げるのかもし れない。

これとは逆に，輪廻転生の概念を持つアボリジニは，「私」をトーテムに投射するような，「私」と外部世界との強い 一体感を持つ9)。つまり，自我は弱く，「私」が肉体の境界を限りなく超え，外部世界という，永遠そのものと究極的に 一致しているように見光る.

現代人は，このようなアボリジニが持つ感覚を，時の流れの中で個人主義やヒューマニズム（人間中心主義）と引き 換えに手放したと考えることもできるだろう。一方で，近年，環境問題の深刻化から，ディープエコロジー ${ }^{10)}$ に代表 される，ヒューマニズムを脱却し，人間と自然との一体性，調和性を深めた，「私」と外部世界との，強いつながりを意 識する思想が生まれつつある.

また，肉体と「私」につきまとう固定観念を捉えな和す思想は，伝統技術の中にも見つけ出すことができる．ヨガで は，悟りには，肉体を「私」と誤認していることに気付く要素が含まれ，この誤りに気付くところから，真の自己への 求道がはじまるとされる11)

これらは，心のあり方や，ある種の技術によって，過去生の存在といら実証不可能な現象を信じることを必要とせず に，永遠と一致することが出来るのではないかといら希望を与えてくれる，そして，それが達成されると，スピリチュ アルの救済により，健康上の不具合が解決されることが予感される.

スピリチュアルの領域は，いまだ，多くの医師が触れていない，畏怖と畏敬，危険性と可能性が混在するブルーオー シャンである．普遍的な共通了解と安全な方法を確立することを前提として，健康の定義や統合医療の領域に，スピリ チュアルを含めることに賛成する立場である.

\section{参 考 文 献}

1) WHO. Basic Documents, Forty-fifth edition, Supplement, 2006. WHO Webpage. http://www.who.int/governance/eb/who constitution en.pdf. page accessed May 5, 2010.

2) 厚生省大臣官房厚生科学課. WHO 憲章に打ける「健康」の定義の改正案について. 第 14 回厚生科学審議会研究企画部会議事録. 資料 1. 健康定義改正案を審議した第 101 回 WHO 執行理事会会議の議事録要旨. 1999.

3) Awofeso N. Re-defining 'Health'. WHO Webpage. http://www.who.int/bulletin/bulletin_board/83/ustun11051/en/. page accessed May 5, 2010.

4) アジア統合医療会議. メディカルトリビューン 2010 年 5 月 13 日版. 東京. メディカルトリビューン. 2010; 43(21): 34-35.

5) ブライアン・L・ワイス，山川紘矢，山川亜希子（訳）。前世療法．東京．PHP 文庫．1996。

6) Stevenson I. A case of the psychotherapist's fallacy: Hypnotic regression to "previous lives." Am J Clin Hypn 1994; 36(3): $188-193$.

7) Linda T. An unusual case of hypnotic regression with some unexplained contents. J Am Soc Psych Res 1990; 84(4): 309-344.

8) リチャード・ドーキンス, 日高敏隆，岸 由二，羽田節子，垂水雄二（訳）。利己的な遺伝子 増補改題「生物一生存機械論」. 東 京. 紀伊國屋書店. 1991.

9) ロバートローラー, 長尾 力 (訳). アボリジニの世界 ドリームタイムと始まりの日の声. 東京. 青土社. 2003.

10) Næss A. The shallow and the deep, long-range ecology movement. Inquiry 1973; 16: 95-100.

11) スワミ・スリ・ユクテスワ, PRF 日本会員 (訳)。聖なる科学一真理の科学的解説一。東京. 森北出版. 1983. 